\title{
The Difference in The Activity of Ethanol Extracts of Leaves of Anti Diabetic tin (Ficus Carica 1.) Leaf, Rambutan (Nephelium Lappaceum) and Persimmon (Diospyros Ft L) on The White Mancit on Streptozotocin Induced
}

\author{
Nurlinawati $^{1}$, Kamariyah $^{2}$, Yosi Oktarina ${ }^{3}$, Sri Mulyani ${ }^{4}$ \\ 1,2,3,4 Prodi Nursing University Of Jambi
}

\begin{abstract}
Diabetes mellitus is a metabolic syndrome most public figures around the globe with events $1-8 \%$. This disease occurs when insulin in insulin production or tidakcukup may not function properly or the amount of insulin enough but it works less well characterized by high levels of sugar in the blood. The Research Design used in this research is experimental design pre test and post test design group, where only when the post test (end) only performed measurements. Research use only post test where observations are conducted as many as 3 times at the time after thera-py/experiment. Observations made after experiment (X 2) called the Post Test. It is known that a group of white male mice strain spreague dawley fed leaves etha-nol extract rambutan (Ficus carica 1.), shows a decrease in blood sugar levels better when compared to the Group of esktrak penginduksi with a persimmon the same form of induction of streptozoto-cin. Ethanol extracts of leaves of Rambutan (Nephelium lappaceum) Note can lower the blood sugar levels of $9 \mathrm{mg} / \mathrm{dl}$ and persimmon (Diospyros $\mathrm{ft} \mathrm{L}$ ) can lower the blood sugar levels of 5.3 $\mathrm{mg} / \mathrm{dl}$, while the leaves of Tin (Ficus carica 1.) showed can increase blood sugar levels in mice white male spreague dawley strain induced streptozotocin.Keyword: self-acceptance, chronic kidney failure, hemodialysis.
\end{abstract}

Keyword: Streptozotocin, Rambutan Leaves, Leaf of Tin and Persimmon.

Received 04 February 2019 | Revised 14 May 2019| Accepted 26 January 2019

\section{Introduction}

Diabetes mellitus is a metabolic syndrome most public figures around the globe with events 1$8 \%$. This disease occurs when insulin in insulin production or tidakcukup may not function properly or the amount of insulin enough but it works less well characterized by high levels of sugar in the blood. The body is not able to produce insulin because cells of Langerhans islets undergoing $\beta$ inflammation caused by the presence of viruses such as cochsakie virus, rubella,

*Corresponding author at: Prodi Nursing University Of Jambi 
cito megalo virus (CMV), herpes and others. Lack of insulin causes hormone disruption biochemical pro-cesses in the body, i.e. a decrease in glucose ambilan into the cells and an increase in glu-cose from the liver into the circulation. Insulin helps the process of destruction and absorp-tion of glucose, fatty acids and amino acids. When insulin is not produced by the pancreas or insulin resistance occurs then the levels of glucose in the blood is increased so that the kidneys are not able to process the glucose and expelled through the urine. Hereditary factors and obesity and lack of exercise great-ly influence diabetes mellitus (Kariadi, 2009).

Diabetes is characterized by hiper-glikemi (elevation of blood glucose levels) who cause various metabolic disorders in the metabolism of short term and long term danprotein fat causes a change of the flow rate that irreversibel. Long-term manifesta-tions of diabetes are can cause some compli-cations as well as microvascular makrovasku-ler (Brahmachari, 2011).

The data of the WHO (World Health Organization) showing the 10 countries with the largest number of sufferers of diabetes mellitus in the world is the United States, China, India, Indonesia, Japan, Pakistan, Rus-sia, Brazil, Italy, and Bangladesh. Indonesia ranks fourth. It is estimated by the year 2025 will be an increase in the number of sufferers of diabetes mellitus from 5 million in 1995 to 12 million sufferers of diabetes mellitus in the world. The number of diabetics in Indonesia is expected to improve the doubled from 8.4 million in 2000 into 21.3 million people by the year 2030. Unhealthy eating patterns are thought to be one of the factors that influence (Munadjad, 2010).

Therapy for diabetes glucose-lowering treatment generally use the blood that had some flaws. Intensive therapy with menggunakanpenurun glu-cose will increase the risk of the occur-rence of hipoglikemi kalilipat 2 heavy mortality, increases of $19 \%$ and increase cardiovascular death of $43 \%$ (Bous-sageon et al., 2011). The high prevalence, treatment costs of diabetes has become a problem for negaramaupun and threats to individuals. Prevention of diabetes since the beginning is very important to do. Prevention and treatment with herbs for diabetes generally showed good efficacy and safety (Park, 2011).

Therapy of diabetes mellitus that take a long time allow the occurrence of usage together with herbal drugs and oral antidiabetika. Based on research in 11 Clinics Depok 2012, 101 of those re-spondents, a total of $52.47 \%$ use anti di-abetic herbal and $47.53 \%$ use ADO in-stead. Patients as much as $54.27 \%$ as user antidibetes, it turns out that using a com-bination of ADO and anti diabetic herbal of $71.70 \%$, whereas $28.30 \%$ use anti dia-betic herbal (Adhitia, 2012).

In response to the diabetes, the drug only is the complement of the diet. The drug need only be given if arrange-ment is not the most nutritious diet con-trolling blood sugar levels. Oral anti dia-betic drugs may be useful to sufferers who are allergic to insulin or doesn't use insulin injections. While its use should be understood, that there is compliance with the indications, doses without causing hypoglycemia. Oral anti diabetic drugs because most give unwanted side effects, then experts developed a system of tradi-tional medicine for diabetes mellitus that is relatively safe (Trisnawati, 2013). 
The last few years, secondary me-tabolites of plants has been widely scruti-nized as a source of medicinal agents. Treatment of diabetes mellitus can be done medically with modern medicines and injections but because of the high cost of medical pengobatancara is some-times hard to do. Diabetes mellitus can also be overcome by utilizing natural treatment plants, therapeutic drugs. Nu-tritious plant remedies can be obtained easily, it can be quoted directly for fresh consumption or can be drained. There-fore, the traditional treatment with me-dicinal plants into alternative steps to overcome it ("city, 2004).

More than a thousand plants dilaporkanmempunyai anti diabetic ef-fect. The mechanism of action of hypo-glycemic plant such as the stimulation of insulin production, increased insulin sen-sitivity, or inhibition of intestinal amylase (Bhat, 2011).Lebih dari 400 jenis tana-mantelah dilaporkan dapat digunakan un-tukpengobatan alternatif dan komple-menter diabetes. Salah satu tanaman yang digunakan dalam pengobatan diabetes adalah daun Tin(Ficus carica L) (Kiran, 2011)

Fig is one of the Moraceae tana-manfamili widespread in subtropical or daerahtropis. In Indonesia, the leaves are used as a remedy for tin overcome dis-ease, kidney stones, hypertension and di-abetes. The activity of the leaf of tin that has been reported is as an antioxidant, hepatoprotektan, antimicrobial, antibacte-rial, antipyretic, imunomodulator, anti diabetic, anti inflammatory, anti cancer and (Ahaddin, 2014). Based on the results of the research been done, it was reported that water and methanol extracts of de-coction daridaun tin capable of lowering blood sugar levels. Tin leaves contain al-kaloids, saponins, $\beta$-setosterols, polyphenols and flavonoids. Flavonoid com-pounds, $\beta$-setosterols, and polyphenols is reported can serve as anti diabetic (Khan, 2011).

One of the other nutritious crops as anti diabetic it is rambutan (Nephelium lappaceum 1.). Plant rambutan (Nepheli-um lappaceum 1.) has been widely known by the people of Indonesia and spread over a wide area, so easily obtained. Em-pirically known leaves rambutan is used to overcome the diarrhea, fever, and dis-color the hair (Dhalimartha, 2014).

Persimmon (Diospyros $\mathrm{ft} \mathrm{L}$ ) in Greece is defined as a food of the God aka the food of the gods has a pretty good nutritional value. Persimmon fruit contains tannins and phenolic com-pounds. Phenol compounds is one of the types of components that are essential to the health of phytochemicals. Com-pounds of phenols in persimmon fruit can act as an antioxidant to inhibit the prosesoksidasi way and the process of the formation of free radicals. Antioxidant properties that may prevent the onset of various diseases, such as cancer, diabetes, and heart disease (Astawan, 2014).

Persimmon also is rich in antioxi-dant likopen that serves as a deterrent to cancer, phytochemicals lutein, beta caro-tene and fiber. The content of polyphe-nols in dalamkesemek can lower the bad cholesterol that causes diabetes mellitus because it can suck out of insulin, where-as the pancreas can't make enough insulin to overcome a shortage of insulin, so the sugar 
levels in the blood going up and can lead to heart disease. In use in the community, the persimmon is used to treat diabetes mellitus is as much as 500 grams per day (Utomo, 2007).

This research seeks to obtain infor-mation that the ethanol extract daunTin (Ficus carica 1.), leaf Rambutan (Nephe-lium lapmampu lowers blood sugar levels and cholesterol in mice white male sprea-gue dawley strain induced streptozotocin diabetes, so the results of this research can help in the selection of the diabetes mellitus therapy better yet.

\section{Research Methods}

The research design used in this research is experimental design pre test and post test de-sign group, where only when the post test (end) only performed measurements. Re-search use only post test where observations are conducted as many as 3 times at the time after therapy/experiment. Observations made after experiment (X 2) called the Post Test.

\section{Description}

01 : Pre -Post Test (Measuring sugar levels before and after the awarding of the extract of the fruit tin)

02 : Pre -Post Test (Measuring sugar levels before and after the awarding of the rambutan) leaf extract

03 : Pre -Post Test (Measuring sugar levels before and after infusion persimmon)

\section{Research Result and Discussion}

The results of the testing activity of anti-diabetes mellitus type II against white male mice strain spreague dawley which are performed with the use of eth-anol extracts of leaves of Tin (Ficus cari-ca 1.) leaf, rambutan (Nephelium lappace-um 1.) and persimmon (Diospyros $\mathrm{ft} \mathrm{L}$ ) in rats white male spreague dawley strain induced streptozotocin. From the obser-vations indicate that the infusion of per-simmon was able to give the effect of type II antidiabetesmelitus, because with the awarding of the ethanol extracts of leaves of Tin (Ficus carica 1.) with the dose capable of lowering glucose levels dalamdarah, as shown in the table the following:

Tabel 1. Research Result

\begin{tabular}{|c|c|c|c|c|}
\hline \multirow{2}{*}{ treatment } & \multicolumn{4}{|c|}{ Time } \\
\cline { 2 - 5 } & $\mathrm{T}_{1}$ & $\mathrm{~T}_{2}$ & $\mathrm{~T}_{3}$ & $\mathrm{~T}_{4}$ \\
\hline Rambutan Leaf Extract & 211 & 206 & 196 & 188 \\
& & & & \\
\hline
\end{tabular}




\begin{tabular}{|l|c|c|c|c|}
\hline Tin Leaf Extract & 230 & 232 & 225 & 217 \\
\hline Persimmon Extract & 223 & 220 & 213 & 206 \\
\hline
\end{tabular}

Description :

$\mathrm{T} 1$ = Rat blood sugar levels the day after 3 day observation

$\mathrm{T} 2$ = Rat blood sugar levels the day after 6 day observation

T3 = Rat blood sugar levels the day after 9 day observation

$\mathrm{T} 4$ = Rat blood sugar levels the day after 12 day observation

It is known that the male group of spreague dawley rats given ethanol extract from rambu-tan leaves (Ficus carica L) showed a better decrease in blood sugar levels compared to the persimmon extract group with the same induction in the form of streptozotocin induc-tion. However, the highest increase in blood sugar levels was shown by the group of tin leaves (Nephelium lappaceum L), where there was an increase in large blood sugar levels on the 6th day of $232 \mathrm{mg} / \mathrm{dl}$.

Because the normal blood glucose level of normal mice is $180-210 \mathrm{mg} / \mathrm{dl}$, the rambutan leaf extract group shows a hyperglycemic state because it exceeds $210 \mathrm{mg} / \mathrm{dl}$ and the persimmon extract group has a hyperglycemic state because it exceeds $210 \mathrm{mg} / \mathrm{dl}$, but is normal in measurements on day $12(206 \mathrm{mg} / \mathrm{dl})$. The increase in levels indicated by the rambutan leaf extract group and persimmon extract showed a not too large increase in lev-els compared to the fig leaf extract group, this was due to the administration of streptozoto-cin as a drug to increase blood sugar levels in male white rats spreague dawley strains which also could raise blood sugar levels. The effect of decreasing blood sugar levels began to oc-cur on the 6th day after administration of rambutan leaf extract (T2), while the persim-mon extract test showed a decrease in blood sugar levels starting on the 12th day (T4) and tin leaf extract preparation had not shown a decrease in sugar content blood in male white rats spreague dawley strains on the day

It is known that the male group of spreague dawley rats given ethanol extract from rambu-tan leaves (Ficus carica L) showed a better decrease in blood sugar levels compared to the persimmon extract group with the same induction in the form of streptozotocin induc-tion. However, the highest increase in blood sugar levels was shown by the group of tin leaves (Nephelium lappaceum L), where there was an increase in large blood sugar levels on the 6th day of $232 \mathrm{mg} / \mathrm{dl}$.

Because the normal blood glucose level of normal mice is $180-210 \mathrm{mg} / \mathrm{dl}$, the rambutan leaf extract group shows a hyperglycemic state because it exceeds $210 \mathrm{mg} / \mathrm{dl}$ and the persimmon extract group has a hyperglycemic state because it exceeds $210 \mathrm{mg} / \mathrm{dl}$, but is normal in 
measurements on day $12(206 \mathrm{mg} / \mathrm{dl})$. The increase in levels indicated by the rambutan leaf extract group and persimmon extract showed a not too large increase in lev-els compared to the fig leaf extract group, this was due to the administration of streptozoto-cin as a drug to increase blood sugar levels in male white rats spreague dawley strains which also could raise blood sugar levels. The effect of decreasing blood sugar levels began to oc-cur on the 6th day after administration of rambutan leaf extract (T2), while the persim-mon extract test showed a decrease in blood sugar levels starting on the 12th day (T4) and tin leaf extract preparation had not shown a decrease in sugar content blood in male white rats spreague dawley strains on the day.

\section{Research Conclusion}

Ethanol extract of Rambutan leaves (Nephelium lappaceum) is known to reduce blood sugar levels by $9 \mathrm{mg} / \mathrm{dl}$ and persimmon (Diospyros kaki L) can reduce blood sugar levels by $5.3 \mathrm{mg} / \mathrm{dl}$, while Tin leaves (Ficus carica L) show can increase blood sugar levels in male white rats spreague dawley streptozotocin induced.

\section{REFERENCES}

[1] Adhitia. 2012. Perspective Effects of the Use of Antidiabetic Herbs Along with the Use of Oral Antidiabetic Drugs in Type 2 Di-abetes Mellitus Patients in Depok Municipality Health Centers. Indonesian Nursing Journal, Volume 16 No. 3, November 2012.

[2] Ahaddin. 2014. Effect of Fruit Extract of Tin Water (Ficus carica L.) on Fasting Blood Glucose Levels of Wistar (Rattus norvegicus L.) Male White Mice Induced by Alloxan Monohydrate. Jakarta: Makara Indonesia Journal Vol. 4 No. 1.

[3] Astawan. 2014. Medicinal Plants for Diabetes, High Blood Pressure, and Cholesterol. Jakar-ta: Agromedia.

[4] Boussageon. 2011. Approaches to Treatment of Type 2 Diabetes. Journal of Diabetes Care Vol. 27.

[5] Brahmachari. 2011. Bio-Flavonoids With Promising Antidiabetic Potentials: A Critical Survey. Canadian Medical Association Vol. 172.

[6] Corwin. 2009. Pathophysiology Pocket Book. Jakarta: EGCeterized Book Publishers.

[7] Dalimartha. 2014. Digest of Indonesian Effi-cacious Medicinal Plants. Cetakan IV, Jakar-ta: PT. Digest Mediatama.

[8] Kariadi. 2009. Tips for Overcoming Diabetes, Hypercholesterolemia, Stroke. Bandung: Qanita Publisher.

[9] Kiran. 2011. Effect of Moderate Intensive Physical Activity of Aerobes and Weight on GLUT4 Gene Expression in Wistar Strain Mice Given Ethanol Extract of Phyllanthus Niruri L. Compared to Separate Intervention: Bandung: Padjadjaran University. 
[10] Munadjad. 2010. Evaluation of T2DM Related Knowledge and Practices of Omani Patients. Saudi Pharm Journal. Oman: Oman Medical College.

[11] Potter \& Perry. 2010. Textbooks on Funda-mental Nursing: Concepts, Processes, and Practices. Edition 6. Jakarta: EGCeterized Book Publishers.

[12] Trisnawati. 2013. Risk Factors for the Occur-rence of Type II Diabetes Mellitus in the Cengkareng District Health Center, West Ja-karta. Health Scientific Journal Vol. 8, No. 1, 2013.

[13] Sudoyo. 2009. Textbook on Internal Medicine. Edition 4. Jakarta: Publisher FKUI Perspective Effects of the Use of Antidiabetic Herbs Along with the Use of Oral Antidiabetic Drugs in Type 2 Diabetes Mellitus Patients in Depok Municipality Health Centers. Indone-sian Nursing Journal, Volume 16 No. 3, No-vember 2012. 